Dunton, C., \& Kitchen, V. (2014). Paradiplomatic policing and relocating Canadian foreign policy. International Journal, 69(2), 183-197. Copyright (C) The Authors 2014 . Reprinted by permission of SAGE Publications. https://doi.org/10.1177/0020702014525903

\title{
Paradiplomatic policing and relocating Canadian foreign policy
}

\section{Veronica Kitchen}

University of Waterloo and Balsillie School of International Affairs, Waterloo, Ontario

\section{Caroline Dunton}

University of Ottawa, Ottawa, Ontario

This is the final submitted copy for the purposes of open-access archiving. For accuracy, please cross-reference with the published version:

Dunton, Caroline, and Veronica Kitchen. "Paradiplomatic policing and relocating Canadian foreign policy." International Journal 69, no. 2 (2014): 183-197.

\footnotetext{
Abstract

Even though they claim to recognize that the boundaries between domestic and international security have eroded, scholars of Canadian paradiplomacy have tended to ignore the security-oriented paradiplomatic activities undertaken by sub-national actors in Canada. However, policing paradiplomacy is, in our view, a perfect case for understanding how paradiplomacy in security can change the relationship between the state and its citizens. Through an examination of the paradiplomatic activities of the RCMP, the Sureté du Québec, and the Vancouver Police, we show how the role of the informal, the danger of mission creep, and the shaping of foreign policy from the margins work to shift how we think about where foreign policy happens.
} 


\section{Keywords}

security, police, paradiplomacy, transgovernmental, foreign policy

In recent years, we have seen the rise of Canadian police actors engaged in activities at or outside of Canada's borders. The Royal Canadian Mounted Police (RCMP) and the American Coast Guard share patrol vessels to jointly protect boundary waters. The Sureté du Québec (SQ) sends liaison officers to police agencies in several foreign countries. The Vancouver Police Department (VPD) trains American National Guard Units in Washington. While such transgovernmental linkages are a dominant feature of globalization and are widely recognized to have the capacity to strengthen or erode the power of the state, scholars of foreign policy have rarely considered transnational security relations to be cases of paradiplomacy. We argue that not only does transnational security policing in Canada represent paradiplomacy, it also provides a meaningful lens through which to consider the question of where foreign policy happens. Security is generally considered to be a core function of the central government of the state. Like the practices of foreign policy, the practices of security draw boundaries between inside and outside, crime and security, citizen and threat. Changing our conception of who is responsible for security should lead us to ask fundamental questions about where foreign policy happens and how the diplomacy of provinces and cities can reshape the relationship between the state and the citizen. As police actors shape foreign policy, decisions are even further diffused beyond the federal government, which changes the 
channels of accountability for strategic decision making, and therefore the cohesiveness of foreign policy as a whole.

Transnational policing happens in a liminal space between formal state powers at the hands of those who do not traditionally have such power. ${ }^{1}$ It occurs at a remove from the traditional foreign policy-making arms of the state, such as the foreign ministry and the military, even as it blurs the line between policing and military action, crime and threat. We argue that this liminality shapes the relationship between states and citizens through the role of informal cooperation, process laundering and mission creep, and the increasing tendency of foreign policy to be shaped from the margins, rather than from the centre.

\section{Paradiplomacy and transgovernmental policing in Canadian foreign policy}

The literature on the role of provinces (and to a lesser degree, cities) in Canadian foreign policy is fairly comprehensive. However, as Christopher Kukucha's contribution to this special issue makes clear, it focuses largely on trade and, in the case of Quebec, cultural diplomacy. In two recent surveys on the role of provinces in Canadian foreign relations security is omitted entirely ${ }^{2}$ or mentioned only briefly. ${ }^{3}$ We argue that this is a significant omission. Scholars of Canadian national security have clearly recognized the erosion of

\footnotetext{
${ }^{1}$ Ben Bowling and James Sheptycki, Global Policing (Thousand Oaks, CA: SAGE Publications, 2012), 3.

${ }^{2}$ Christopher Kukucha, "Dismembering Canada? Stephen Harper and the foreign relations of Canadian provinces," Review of Constitutional Studies 14, no. 1 (2009): 2152.

${ }^{3}$ Kim Richard Nossal, Stéphane Roussel, and Stéphane Paquin, International Policy in Canada (Toronto: Pearson Education, 2011), 301-302.
} 
the links between the domestic and the international and its effects on security governance, ${ }^{4}$ but few explicitly pitch their contributions in terms of foreign policy. ${ }^{5}$

Similarly, scholars of transnational and transgovernmental policing ${ }^{6}$ usually ignore the foreign policy implications of policing activity abroad. Like scholars of national security, scholars of transnational policing recognize the dissolution of the barriers between the domestic and the international, and ascribe it to changes in the nature of the threats police are required to counter that originate from this dissolution. Threats are perceived to originate from anywhere, not just from other states. The discourses of security of the past decade have been dominated by terrorism, a threat that emerges not just at borders and ports of entry, but potentially anywhere, and that can be nearly impossible to predict. In response to the (perceived) transnationalization of the threat to security, policing has simultaneously become securitized ${ }^{7}$ and transnationalized. That is, not only are police departments taking on more and more functions that relate to national security; they are engaging in more and more functions that lead them to work across borders. Scholars of transnational policing and the securitization of policing recognize the role of police departments in constructing new spaces of security and insecurity, and new structures of security governance. Peter K. Manning further argues that "transnational

\footnotetext{
${ }^{4}$ Colleen Bell, The Freedom of Security: Governing Canada in the Age of CounterTerrorism (Vancouver and Toronto: UBC Press, 2011).

${ }^{5}$ But see Mark Salter, "Citizenship, borders, and mobility: Managing the population of Canada and the world," and Veronica Kitchen, "Where is internationalism? Canada-US relations in the context of the global and the local," in Heather A, Smith and Claire Turenne Sjolander, eds., Canada in the World (Don Mills: Oxford University Press, 2013), 146-163 and 164-182.

${ }^{6}$ Policing activity undertaken by a governmental actor in co-operation with a governmental actor in another state.

${ }^{7}$ Christopher Murphy, "'Securitizing' Canadian policing: A new policing paradigm for the post 9/11 security state?," The Canadian Journal of Sociology / Cahiers Canadiens de Sociologie 32, no. 4 (December 2007): 449-475.
} 
policing is partly about the regulation of a new, growing and resonant kind of social space" ${ }^{\prime 8}$ and that police are in the process of growing a capacity to deal with it. There is a popular conception that "it takes a network to fight a network" - that the only way to address modern terrorism is through transnationalism. ${ }^{9}$

The transnationalization of security threats, however, is not simply an objective process to which police are responding. Through the boundary-creating processes of security and foreign policy, relevant state actors also shape their environments and what is considered to be a threat. This, in turn, shapes the relationship between the state and its citizens. As security policing leads police into cooperative arrangements with colleagues across borders, patterns of accountability necessarily change. The politics of security are often the politics of exceptionalism. Many things can be done in the name of security that would not otherwise be permissible. As the boundaries between crime and policing, and inside and outside blur, so too do the boundaries between those who are considered citizens and those who are considered outsiders.

In this article, we discuss transgovernmental policing activities undertaken by Canadian governmental actors at the federal (RCMP), provincial (Sureté du Québec), and municipal (VPD) levels. All transgovernmental policing activity of necessity involves information sharing. Without information sharing, no other policing cooperation is

\footnotetext{
${ }^{8}$ Peter K. Manning, "Policing new social spaces," in J.W.E. Sheptycki, ed., Issues in Transnational Policing(New York, NY: Routledge, 2000), 180.

${ }^{9}$ Nadia Gerspacher and Véronique Pujas, "International police organizations: The missing link to effective cooperation," in Lemieux, ed., International Police Cooperation: Emerging Issues, Theory and Practice (Portland, OR: Willan Publishing, 2010), 241-259.
} 
possible. ${ }^{10}$ The most prevalent form of this information sharing is liaison policing, where police officers are posted in police agencies abroad. Each of our three paradiplomatic actors also engages in mission-specific or standing operational policing cooperation. We argue that standing police cooperation is most likely to reshape the relationship between citizens and the state.

\section{Transgovernmental liaison policing}

Because it is a federal agency, the RCMP's transnational activities are not paradiplomatic in the conventional sense. However, these activities are still significant, particularly since the RCMP's national security operations have grown in number and security threats to Canada have come to be seen as emerging from anywhere, at home or abroad. In Canada, 37 RCMP police liaisons of the International Policing branch now operate in 26 locations abroad. They have a mandate to "maintain a link between law enforcement agencies in Canada and in their countries of accreditation in order to facilitate bilateral cooperation to advance criminal matters that have a Canadian connection." ${ }^{11}$ RCMP liaison officers most commonly facilitate information sharing, assist foreign police departments with investigations with a Canadian connection, and facilitate mission-specific cooperation. A recent case where liaison officers are likely to have been involved is that of Jeffrey Delisle, the Canadian naval sub-lieutenant allegedly working as a Russian spy: it has recently come to light that even though the Canadian Security and Intelligence Service

\footnotetext{
${ }^{10}$ Adam Molnar, "The geo-historical legacies of urban security governance and the Vancouver 2010 Olympics” (Social Sciences Research Network, 15 April 2013), 17. http://papers.ssrn.com/sol3/papers.cfm?abstract_id=2251531 (accessed 29 May 2013). 11 "International Operations Branch," Royal Canadian Mounted Police/Gendarmerie Royale Du Canada, 20 January 2010, http://www.rcmp-grc.gc.ca/ip-pi/iob-soi-eng.htm (accessed 29 May 2013).
} 
(CSIS) had evidence showing Delisle passing information to Moscow, it was

Washington's Federal Bureau of Investigation (FBI) that alerted the RCMP to Delisle's activities. $^{12}$

Transnational liaison policing at the provincial or municipal level is comparatively rare. The only province to engage in it is Quebec, and there are no Canadian cities with formal, standing liaison programs. ${ }^{13}$ The SQ engages in technical and operational cooperation in public safety and security with different partners. Its program seems to focus primarily on improving police practice and learning from other police forces. Liaison personnel from the SQ are sent to foreign countries with long-term cooperation agreements. Cooperation in these liaison exchanges includes police education, criminal investigation, emergency measures, community policing principles, road safety, counter terrorism, intelligence, management, and crime prevention. Liaisons have been established in France, Belgium, and Switzerland and are in the process of being developed in the Netherlands, Germany, Italy, Spain, and the UK. ${ }^{14}$ The SQ also has the capacity to share counter-terrorism information with the United States. Nine cooperation agreements have been signed with international partners since 2001. By sharing practices and expertise and gathering information overseas, the SQ aims to

\footnotetext{
12 Jim Bronskill and Murray Brewster, "Jeffrey Delisle case: CSIS secretly watched spy, held file back from RCMP," Toronto Star, 26 May 2013, http://www.thestar.com/news/canada/2013/05/26/jeffrey_delisle_case_csis_secretly_watc hed_spy_held_file_back_from_rcmp.html (accessed 14 December 2013).

${ }^{13}$ As far as we know, the New York Police Department (NYPD) is the only municipal police force with standing liaison officers in other police departments abroad. London's Metropolitan Police also sends liaisons, but they serve a dual role as representatives of the national police department.

14 “Coopération Technique," Sûreté du Québec, 22 October 2008, http://www.sq.gouv.qc.ca/mission-et-services/expertise-internationale/cooperationtechnique-activite-internationales-sq.jsp (accessed 29 May 2013).
} 
improve its ability to fight crime and bring innovative solutions to public safety and security challenges. It also aims to build and enhance cooperation networks to be able to share expertise and consult with other countries as well as to improve evaluation, ethics, training, and management through these networks. ${ }^{15}$

As appropriate, the RCMP helps the SQ liaison agents connect overseas, assists with prevention and detection services for international crimes that break Canadian or Quebec law, and collaborates with the SQ in major Canadian investigations that have foreign ramifications. Further, SQ officers are posted to the Interpol offices in Ottawa and to the Montreal Integrated National Security Enforcement Team (INSET). ${ }^{16}$ Much of the SQ's collaboration on security issues has been with France and together they have created an international network of francophone police, Francopol. Francopol's role is to share best practices, research, training, and education. There are a few other limited examples of standing provincial liaison policing. For instance, the Ontario Provincial Police has an officer seconded to the Michigan Regional Operational Integration Center, which is "intended to be a mechanism for leveraging the capabilities of the law enforcement community in an effort to detect, deter and prevent any security risks or threats along the Detroit River and Lake St. Clair area." ${ }^{17}$

\footnotetext{
${ }^{15}$ Ibid.

16 “Activités Internationales," Sûreté du Québec, 21 December 2010, http://www.sq.gouv.qc.ca/mission-et-services/expertise-internationale/activitesinternationales-police-nationale-sq.jsp (accessed 29 May 2013).

${ }^{17}$ RCMP, "RCMP to Join New Operational Integration Centre in Detroit," Royal Canadian Mounted Police/Gendarmerie Royale du Canada, 24 April 2011, http://www.rcmp-grc.gc.ca/on/news-nouvelles/2011/11-03-24-windsor-eng.htm (accessed 14 December 2013); Customs \& Border Protection, "CBP Opens New Operational Integration Center in Mich.," Government, CBP.gov, 20 March 2011, http://www.cbp.gov/xp/cgov/newsroom/highlights/2011/new_op.xml (accessed 19 September 2013).
} 
The most noteworthy example in Canada of transnational policing at the municipal level is the Vancouver Police Department (VPD). It is the only municipal police force in Canada to have developed a sustained relationship with other actors outside of Canada, through its Military Liaison Unit (MLU). ${ }^{18}$ The MLU was established in the run-up to the Vancouver Olympic Games to improve the communications and training relationships between the VPD and the military. As the unit has grown, however, it has begun to engage in joint exercises several times a year with the US National Guard in Yakima, Washington. While this is not an operational partnership, it clearly goes beyond the liaison policing described above. The goal is for the police to learn how military technologies and tactics might assist with urban policing, and for the military to learn how police tactics might assist with an urban warfare mandate. Adam Molnar argues that the Vancouver Olympics served as a "multiplier" for the VPD, providing it with an opportunity to acquire specialized training and equipment. The "Olympic boost" meant that the VPD was better equipped than some military brigades..$^{19}$ This put the organization in an excellent position to export its knowledge and skills beyond Canadian borders. Under an agreement with the US Army, the MLU trains US National Guard soldiers in urban tactical operations, while the VPD's experts learn Explosive Ordinance Disposal and train with Unmanned Aerial Vehicles in American airspace. ${ }^{20}$ The agreement allows the US National Guard to circumvent the Posse Comitatus Act, which states that the federal military cannot be involved in law enforcement on domestic soil. Receiving training from a foreign police department rather than the US Army nicely

${ }^{18}$ On the Military Liaison Unit, see Molnar, "Geo-historical legacies.”

${ }^{19}$ Ibid., 13 .

${ }^{20}$ Ibid., 18. 
avoids any legal dilemmas. ${ }^{21}$ The National Guard's use of VPD training, therefore, can be seen as a type of process laundering, using transnational relationships to get around domestic restrictions. The MLU also trains personnel in traditional policing who go on to serve in military police roles in Afghanistan and Sudan ${ }^{22}$ — clearly showing that the phenomenon of transnational policing is shaped by and shapes the erosion of the divide between the domestic and the international.

These policing activities are significant because they provide further evidence that the national security function of the state has been adopted by actors not just across the federal government, but also beyond it. The state can no longer speak with one voice in security diplomacy, especially as concerns terrorism, perceived by Canadians to be a significant threat. Even more significant for the study of foreign policy, however, are cases where Canadian actors work directly with foreign actors in integrated units.

\section{Integrated transgovernmental policing}

Ever since 9/11, it has become conventional wisdom that a lack of cooperation among domestic security and intelligence agencies as well as between security agencies across borders has inhibited national and international security. In Canada, integrated policing units have brought together professionals from different parts of the security bureaucracy with the goal of improving information sharing and, in some cases, operational capacity. In rarer cases, these teams have integrated personnel from Canada and the United States.

While the integrated model has been used for some time in Canada for border enforcement and prosecuting organized crime, more recently more ambitious teams have

21 Ibid., 19.

${ }^{22}$ Ibid. 
developed which focus on national security. In 2002, the RCMP established integrated units called Integrated National Security Enforcement Teams (INSETs). These bring together experts from federal, provincial, and municipal police forces, Canadian Border Services, and CSIS. While they do not include foreign nationals, the INSETs work closely with police forces abroad, and most intensively with the United States. At a minimum, this cooperation includes information sharing, but in some cases the information sharing is so intensive and coordinated that it might more properly be called mission-specific cooperation. This seems to have been the case with the recent “Operation Smooth,” where the Toronto and Montreal INSETs cooperated with the New York Joint Terrorism Task Force (JTTF) — another domestically integrated team - to coordinate the timing of three arrests of individuals suspected of planning to bomb a VIA rail train. ${ }^{23}$ There has been some suggestion in the media that the Americans would have preferred to wait longer to make an arrest, but the Canadian decision to go ahead forced their hand. ${ }^{24}$ This suggests that operational cooperation is imperfect at best.

Canada and the United States also police together in standing, integrated teams. The oldest of these, Integrated Border Enforcement Teams (IBETs), were designed to control the border for the protection of both countries. Since their establishment, standing integrated policing teams have become more ambitious. The Shiprider program, for example, was created in 2005 to police the boundary waters of Canada and the United

\footnotetext{
${ }^{23}$ Stewart Bell and Graeme Hamilton, "Third suspect related to alleged VIA Rail terror plan discussed bacteria plot to kill '100, 000 people': Documents," National Post, 9 May 2013, http://news.nationalpost.com/2013/05/09/fbi-arrested-third-suspect-related-toalleged-via-rail-terror-plot/ (accessed 14 December 2013).

${ }^{24}$ Jessica Murphy, "Feds skirt allegations RCMP rushed terror alerts," Toronto Sun, 24 April 2013, http://www.torontosun.com/2013/04/24/feds-skirt-allegations-rcmp-rushedterror-arrests (accessed 14 December 2013).
} 
States. Shiprider extended the IBET model to remove "the international maritime boundary as a barrier to law enforcement by enabling seamless continuity of enforcement and security operations across the border, facilitating cross-border surveillance and interdiction, and serving as both a force multiplier and, potentially, as a model for other U.S./Canadian cross-border (integrated) enforcement and security initiatives." After a number of pilot projects, it was finalized and given a set of standard operating procedures in the summer of 2013. ${ }^{25}$ Under the program, Canadian RCMP officers and American Coast Guard officials ride together on the same boats and are deputized to enforce the laws in both countries, with the host state always retaining final jurisdiction.

There has also been talk of extending the IBET/Shiprider model beyond the immediate region of the border. This "NxtGen" policing model was first proposed in the Beyond the Border Agreement of 2011. Progress seems to be hindered by American concerns about having American officers subject to the jurisdiction of Canadian courts when operating in Canada. ${ }^{26}$ Were such an agreement to be implemented, however, several other jurisdictional challenges could arise that might shape Canadian foreign policy from the transnational level. For instance, it is not yet clear how far from ports of entry these integrated teams would be allowed to operate, and under what circumstances. Under the Shiprider agreement, one of the perceived advantages is that of "hot pursuits"; no longer will port-runners be able to flee across the border, leaving their police pursuers on the other side of a jurisdictional boundary. On land, such pursuits have a questionable

25 "Canada-U.S. Shiprider," Royal Canadian Mounted Police, 17 June 2013, http://www.rcmp-grc.gc.ca/ibet-eipf/shiprider-eng.htm (accessed 6 September 2013). ${ }^{26} \mathrm{Jim}$ Bronskill, "Canada-U.S. border: American police want legal exemptions, RCMP says," Huffington Post, 31 July 2013, http://www.huffingtonpost.ca/2013/07/30/bordersecurity-us-police-legal-exemptions_n_3678240.html (accessed 19 August 2013). 
legal status, and one could again imagine a kind of process laundering where an integrated team waits until a suspect is physically in a jurisdiction with preferable laws or sentences. ${ }^{27}$ Would integrated teams be able to investigate and prosecute crimes that occur wholly on Canadian soil and subject to Canadian laws, or would they be limited to inter-jurisdictional crimes, as the CCLA has suggested? ${ }^{28}$ Integrated teams also add an extra wrinkle to secondary information sharing. How far could information collected in Canada by an integrated team be shared with American law enforcement officials beyond those on the team? The creation of IBETs and Shiprider and the proposal for NxtGen clearly reflect Canadian strategic priorities, which have long been shaped by the need to maintain a strong security relationship with the United States. However, as these new cooperative initiatives evolve, it becomes clear that Canadian foreign policy is shaped from the margins, through regulations and laws that may not be affected by democratic processes.

\section{What explains police paradiplomacy in Canada?}

Police departments at all levels have for some time shared information with departments across borders in the service of apprehending criminals. However, more recently, they have also engaged in mission-specific and standing operational cooperation across borders. Provinces and municipalities that engage in operational transnational policing must have both the means and the incentives to do so: in Vancouver, transnational

\footnotetext{
${ }^{27}$ Veronica Kitchen and Kim Rygiel, "Integrated security networks: Less not more accountability," in Margaret Beare, ed., The State on Trial: Policing Protest at the G20 and Beyond (Vancouver and Toronto: UBC Press, forthcoming 2014).

${ }^{28}$ Government of Canada, "What Canadians Told Us: A Report on Consultations on Perimeter Security and Economic Competitiveness Between Canada and the United States," (Ottawa: Department of Foreign Affairs and International Trade, 2011), 33.
} 
policing seems to be a way to exchange techniques with new partners and gain prestige; in Quebec there is a political motivation. Neither example seems to be related to a perceived threat, decentralization of policing and security services, or to a sense that the RCMP cannot protect Vancouver or Quebec. Both examples, though, lend credence to the hypothesis that transgovernmental policing is only tangentially related to a particular threat, and has more to do with entrepreneurship (Vancouver) or the desire to sustain a particular social order (Quebec). The RCMP example more clearly reflects evolving strategic priorities at the national level, but still demonstrates how the changing nature of security policing shapes foreign policy at the margins.

Vancouver's efforts seem to come from the autonomy of police and represent an opportunistic desire for innovation, experimentation, and entrepreneurship within the context of the changing nature of security. Robertson argues that because of the many different forms of Canadian policing (local, provincial, federal), there are many opportunities for innovation that come from varied and independent types of services. ${ }^{29}$ With significant autonomy and the opportunity to begin such innovation during the Olympics, Vancouver was able to easily engage in paradiplomacy.

The existence of the SQ's international presence is more complex and is closely related to Quebec's ownership of its international relations, since it sees questions of security as integral to the global priorities of the province. Quebec has traditionally claimed authority over foreign policy in matters constitutionally assigned to the provinces. The federal-provincial distinction has been harder to uphold over the years, as almost any facet of government activity has an international dimension. Quebec has a

\footnotetext{
${ }^{29}$ Neil Robertson, Neil, "Policing: Fundamental Principles in a Canadian Context." Canadian Public Administration 55, no. 3 (2012): 343-363. , 345.
} 
strong history of paradiplomacy and engagement in international affairs beyond its provincial police force. Primarily, Quebec's paradiplomacy has been driven by nationalism and its desire to assert the unique cultural and linguistic attributes that set it apart from the rest of Canada. ${ }^{30}$

André Lecours argues that in addition to a desire to assert and project its identity, Quebec's paradiplomacy is fuelled by both its considerable power within the federal system and also its sense of competition and conflict with the federal government. ${ }^{31}$ This competition is reflected in the SQ's choice of liaison policing, a program that mirrors the RCMP's activities, as its mechanism for policing paradiplomacy. In short, the SQ's foray into transgovernmental policing is part of a larger paradiplomatic movement and structural context that is motivated by the province's long-standing desire to represent its own affairs (and identity) abroad rather than by a sense that it faces undue threats.

As Canadian police agencies at all levels become more involved in paradiplomacy transnational relationships for a variety of reasons, we can also expect the relocation of foreign policy to agencies and governments beyond the federal to shape and reshape the federal government's relationship to its citizens.

\section{Implications for foreign policy}

Transnational policing in Canada shapes foreign policy by affecting the way the state interacts with its citizens. Security, like foreign policy, is a boundary-making process that

${ }^{30}$ Kim Richard Nossal, The Politics of Canadian Foreign Policy, 3rd ed.(Scarborough, ON: Prentice Hall Canada, 1997), 316.

${ }^{31}$ Ibid., 102. 
defines insiders and outsiders to the state. ${ }^{32}$ This definition of outsiders may be literalpreventing certain groups of people from being admitted to the state in the first placebut also metaphorical — mandating that certain laws apply to those who have the markers of potential terrorists, and others to the rest of us. Transnational policing complicates the boundary-making function of foreign policy in two ways: first, by pluralizing the actors engaged in the governance of security (forcing us to question who does foreign policy) and second, by blurring the boundaries between crime and security, and domestic and international (forcing us to question where foreign policy happens).

Each of the cases reviewed here reshapes boundaries in different ways. The RCMP's liaison policing erodes the boundaries between crime and security, as the RCMP takes on a larger role in national security investigations. Shiprider and NxtGen reshape the way we conceive of the border; the maritime border has become shared jurisdictional space, and if American police officers begin to work on Canadian soil (and vice versa), notions of domestic and international security will become nearly meaningless. The very fact that the province of Quebec and the city of Vancouver engage in police paradiplomacy subverts normal expectations about both policing and foreign policy, but the content of their transnational policing does so even more: the VPD's relationship with the National Guard demonstrates the porous nature of the line between urban policing and urban war; the SQ's liaison program operates just like similar programs undertaken by states. Below, we discuss some specific ways in which paradiplomatic policing in Canada shapes foreign policy.

${ }^{32}$ David Campbell, Writing Security: United States Foreign Policy and the Politics of Identity (Minneapolis: University of Minnesota Press, 1998). 
The role of the informal

Informality matters to paradiplomacy in two ways. First, macro-regionalism—notably NAFTA - tends to create opportunities for policy adaptation by sub-national actors within the new macro-region. ${ }^{33}$ For instance, NAFTA facilitated a number of crossborder economic and environmental cooperation initiatives such as the Pacific Northwest Economic Region (PNWER), the Great Lakes Council of Governors, and the New England Governors/Eastern Canadian Premiers Summit. ${ }^{34}$ Christopher Kukucha dismisses these as "functional issues" somewhat distinct from foreign policy, ${ }^{35}$ but arguably they have provided the structural conditions necessary for more intensive paradiplomatic relationships, such as the secondment of an OPP officer as well as an RCMP officer in Michigan's Operational Integration Center. ${ }^{36}$

Second, informal cooperation, starting with information sharing, can be the foundation of more formal cooperation, or can oil the gears of cooperation in formal structures. Laure Guille writes that "where cooperation exists, there is trust and where there is trust, there is cooperation." ${ }^{37}$ Moreover, "police cooperation at the individual case and practitioner level is driven by efficiency rather than by formal methods of cooperation, which is why personal contacts — and therefore trust—play such a major role

\footnotetext{
33 Ibid., 19.

${ }^{34}$ While some of these initiatives predate the FTA, the integration of the Canadian and American economies has clearly increased their relevance.

${ }^{35}$ Kukucha, "Dismembering Canada?" 23.

${ }^{36}$ Customs \& Border Protection, "CBP Opens New Operational Integration Center in Mich."

${ }^{37}$ Laure Guille, "Police and judicial cooperation in Europe: Bilateral versus multilateral cooperation," in Lemieux, ed., International Police Cooperation, 27; see also Hasan Yon, "Police liaisons as builders of transnational security co-operation," in Ersel Aydinli, ed., Emerging Transnational (In)security Governance: A Statist-Transnationalist Approach, 1st ed. (New York: Routledge, 2010), 124-142.
} 
in efficient cooperation." ${ }^{38}$ Once cooperation is established, bureaucracy, mutual agreements, and regulations structure it, but it is through informal interactions that officers can gain valuable experience and "smooth over some of the bureaucratic processes that may slow down the investigation process." ${ }^{39}$

While "smoothing over"- a very traditional diplomatic goal—is often an implicit or explicit rationale for instituting transgovernmental operations in the first place, informality in the realm of security can change the state's relationship with its citizens. Informal cooperation is often problem-solving cooperation, operating ahead of laws or between them. Moreover, security is often used to justify secrecy, the curtailment of civil liberties, and the invasion of private space. Sheptycki and Bowling ask: "What form of governance is required to ensure that policing power is constrained, legitimated, and held accountable when its social world lies hidden often in the 'transnational space between' formal state powers?" ${ }^{40}$ Even when such forms of governance do exist, there is always a difference between "law in action" and "law in books"- that is, between the rules and the implementation of the rules. ${ }^{41}$

\section{Process laundering and mission creep}

Relatedly, the growth of transgovernmental policing creates opportunities for process laundering or mission creep that can increase the gap between police behaviour and state preferences. Process laundering is like forum shopping. A police actor may choose to disclose information, make an arrest, or engage in particular practices in the legal

\footnotetext{
${ }^{38}$ Guille, "Police and judicial cooperation in Europe," 28.

${ }^{39}$ Yon, "Police liaisons," 132.

${ }^{40}$ Bowling and Sheptycki, Global Policing, 32.

${ }^{41}$ Ibid., 42.
} 
jurisdiction most conducive to what the police actor wishes to do. ${ }^{42}$ By mission creep we mean the adoption of new tasks beyond the mandate of the organization. In some cases, technology may outpace legal change, giving police actors the ability to act in ways that are not sanctioned by the state. ${ }^{43}$ Mission creep may also result from factors such as entrepreneurialism or the routinization of special powers. Both of these concepts affect the relationship between state and citizen because of the challenge to the cohesiveness of foreign policy and established mechanisms for accountability presented by an expansion of mandate or circumvention of local law through process laundering.

Above, we discussed how the proposed extension of Shiprider to land-based cooperation might lead to process laundering and how the VPD facilitates process laundering in the United States for National Guard troops who cannot be trained by their army counterparts. Close cooperation between allies at the state level can also facilitate process laundering at the sub-national level. For instance, the United States and Canada cooperate closely through the Five Eyes intelligence alliance. While Canada's Five Eyes allies have all agreed not to target one another's nationals, the reality of modern communication is that a significant proportion of Canadian communication is routed through the United States. A recent attempt by journalist Colin Freeze to investigate the relationship between CSIS, the RCMP, the Canadian Border Services Agency (CBSA), and Communications Security Establishment Canada (CSE) revealed little — but did confirm that these organizations all make frequent requests to CSE, which is not supposed to spy on Canadians, for assistance with their domestic counter-terrorism

\footnotetext{
42 ibid, 19.

${ }^{43}$ J.W.E. Sheptycki, In Search of Transnational Policing: Towards a Sociology of Global Policing (Aldershot, Hampshire: Ashgate, 2002), 91.
} 
investigations. ${ }^{44}$ While we have no concrete cases of process laundering involving the RCMP, it is not impossible to imagine that Canadian meta-data could be swept up through American surveillance programs, shared with Canadian intelligence agencies and, ultimately, with police through intelligence sharing agreements if the information was thought to be relevant to Canadian security interests. ${ }^{45}$

A related concern for foreign policy is mission creep. Transgovernmental actors may learn new techniques and best practices from their counterparts across borders - and this will often be seen as positive by the sending police agency. However, the gap between what a transgovernmental police actor is tasked to do and what it actually does can grow as a result of these interactions. In Canada, the INSET established in Edmonton was explicitly established to counter threats from "environmental terrorists"- although to date, the attacks have not gone beyond sabotage. ${ }^{46}$ INSETs have also been involved in investigating gangs in the lower mainland, ${ }^{47}$ animal rights activists, ${ }^{48}$ theft of classified

\footnotetext{
${ }^{44}$ Colin Freeze, "Ottawa's eavesdropping spy agency kept well under wraps," Globe and Mail, 29 May 2013, http://www.theglobeandmail.com/news/politics/globe-politicsinsider/ottawas-eavesdropping-spy-agency-kept-well-under-wraps/article12220251/ (accessed 31 December 2013).

${ }^{45}$ Craig Forcese, "10 questions about Canada's Internet spying," Globe and Mail, 11 June 2013, http://www.theglobeandmail.com/commentary/10-questions-about-canadasinternet-spying/article12468197/ (accessed 19 September 2013).

${ }^{46}$ Carrie Tait, "Ottawa launches Alberta counterterrorism unit," Globe and Mail, 6 June 2012, http://www.theglobeandmail.com/report-on-business/industry-news/energy-andresources/ottawa-launches-alberta-counter-terrorism-unit/article4236422/ (accessed 22 June 2012).

${ }^{47}$ Ian Bailey, "Are the police spread too thin?" Globe and Mail, 14 March 2009, http://www.theglobeandmail.com/news/national/british-columbia/are-the-police-spreadtoo-thin/article976918/ (accessed 6 September 2011).

${ }^{48}$ Thomas Walkom, "War on Terror being used as fig leaf," Toronto Star, 20 August 2002. A19.
} 
documents ${ }^{49}$ and forgery and fraud. ${ }^{50}$ While these activities are all very plausibly connected to national security, there is a risk that INSETs become an arm of the government used mainly for activities with only tenuous connections to national security. Canada's goal should be to prevent its INSETs—and other transnational policing endeavours - from becoming extra surveillance capacity for the government, as has been the case with the American Fusion Centers, where there has been a clear mandate shift from the original counter-terrorism focus to a more general crime and surveillance focus, to the detriment of their effectiveness. ${ }^{51}$ The concern here is the potential for logics of security —including exceptionalism, exclusion, and the treatment of everyone as if they are a threat - to pervade more and more spaces. The challenge of terrorism, for instance, is to stop it before it happens. However, terrorism is a low-probability event. Planning an attack can look like planning a crime, and also like living a normal (non-criminal) life. Trying to prevent terrorism thus creates pressures to gather more and more information about civilians and to share it widely — and in the process to classify citizens according to

\footnotetext{
${ }^{49}$ Daniel Leblanc and Jeremy Torobin, "Classified documents stolen from Carney's car; Bank of Canada procedures under review after vehicle was left unattended in downtown Montreal," Globe and Mail, 17 November 2010. A1.

${ }^{50}$ RCMP. "Major Joint Police Operation against a Forgery and Fraud Network." RCMP News Releases, November 25, 2009. http://www.rcmp-grc.gc.ca/qc/nouv-news/comrel/2009/11/091125-eng.htm. (accessed 4 February 2014).

${ }^{51}$ United States Senate, Committee on Homeland Security and Governmental Affairs Permanent Subcommittee on Investigations. Federal Support for and Involvement in State and Local Fusion Centers. United States Senate, 3 October 2012, http://www.hsgac.senate.gov/download/report_federal-support-for-and-involvement-instate-and-local-fusions-centers (accessed 14 December 2013).
} 
their personal (threatening or non-threatening) characteristics, rather than their (criminal or non-criminal) behaviour. ${ }^{52}$

\section{Shaping foreign policy from the margins}

Foreign policy, and in particular security policy, is usually thought to be a key responsibility of the central government of the state. To be sure, foreign policy is built pluralistically, but there is usually some cohesion imparted by the federal government. States are usually loath to cede this control and cohesion to actors beyond their boundaries. This fear is behind the fact that the NxtGen integrated policing units have yet to materialize despite their announcement in the Beyond the Border agreement. As more and more policing actors engage beyond borders in processes and operations that are more intensive than basic information sharing, states may be less able to shape the way they are viewed abroad. Foreign policy may also be shaped by technology and practices inside police forces, and thus outside the democratic structures of the central state. Agencies may work at cross-purposes, forcing the state's hand. The most prominent example in Canadian transgovernmental policing is Project $\mathrm{A}-\mathrm{O}$, the counter-terrorism investigation during which the RCMP violated its own information-sharing regulations and prompted the arrest, by the FBI, of Maher Arar. As is well known, the fall-out from that error profoundly shaped police practice and intelligence sharing not just between CSIS and the RCMP, but also between the RCMP and its foreign partners - and also

\footnotetext{
52 Jude McCulloch and Sharon Pickering, "Pre-crime and counter-terrorism: Imagining future crime in the "War on Terror," British Journal of Criminology 49, no. 5 (2009): 633.
} 
shaped the way Canada was viewed abroad. It could no longer deny complicity in American policies of rendition, even if its complicity was unintentional.

\section{Conclusion}

While security has always been recognized as central to foreign policy, its absence from the analysis of paradiplomacy has been noticeable. This omission is significant; scholars of foreign policy recognize that threats cannot be defined as strictly coming from outside, and that non-central governments often engage in paradiplomacy when global issues intersect with local ones. Nonetheless, scholars have rarely examined policing, one of the more prominent cases where these phenomena intersect. Non-central government transnational policing emphasizes the ways in which actors who are both outside the federal government and outside the normally identified security agencies increasingly shape Canadian security policy. The advantages and drawbacks of the practices of security and diplomacy in which they engage deserve the attention of policy makers and scholars engaged with the governance of Canada's national security, and the foreign policies associated with it.

\section{Acknowledgement}

We are grateful to Karina Sangha for research assistance.

\section{Funding}

This research was funded through an Ontario Early Researcher Award. 


\section{Author Biographies}

Veronica Kitchen is an associate professor of political science at the University of Waterloo and the Balsillie School of International Affairs.

Caroline Dunton is an MA candidate in the University of Ottawa's Graduate School of Public and International Affairs.

caroline.dunton@uottawa.ca 